\title{
Mycobacterium abscessus Skin Infection Associated with Shaving Activity in a 75-year-old Man
}

\author{
Hoon Choi, Yong II Kim, Chan Ho Na, Min Sung Kim, Bong Seok Shin \\ Department of Dermatology, Chosun University of Medicine, Gwangju, Korea
}

Corresponding Author:

Bong Seok Shin, MD, PhD

https://orcid.org/0000-0001-9618-1763

Department of Dermatology, Chosun

University Hospital, 365 Pilmundaero,

Gwangju 61453, Korea

Tel: +82-62-220-3130

Fax: +82-62-222-3215

E-mail: derm75@chosun.ac.kr

Received: August 30, 2018

Revised: November 4, 2018

Accepted: November 5, 2018
Mycobacterium abscessus comprises rapidly growing mycobacteria, and the clinical manifestations of $M$. abscessus skin infection include papule, nodule, ulcer, scar and mixed form. The cutaneous infections have been reported due to minor trauma, cosmetic therapy, acupuncture and disseminated infection. A 75-year-old man presented with pruritic diffuse various sized erythematous papuloplaques and pustules on the neck and chest for 2 months. The cutaneous lesions were spread around the wound of the shaving on the neck. The histopathologic findings were consistent with abscess showing infiltrations of neutrophils and lymphocytes in the dermis and negative findings were observed on immunohistochemical stain including acid-fast bacilli stain. One month later, mycobacterial culture result showed positive findings, and the pathogen was identified by reversetranscriptase polymerase chain reaction with hybridization. The patient was treated with combination of clarithromycin and ethambutol for 5 months and there is no evidence of recurrence after 6 months of follow-up. Herein, we report a case of $M$. abscessus cutaneous infection through minor trauma caused by shaving in the elderly. (Ann Geriatr Med Res 2018;22:204-207)

Key Words: Mycobacterium abscessus, Elderly

\section{INTRODUCTION}

Recent decades have seen a significant increase in the number of nontuberculous mycobacteria (NTM) infections worldwide. ${ }^{1)}$ Although the epidemiology of NTM infection remains unknown, NTM infections are more likely to occur in elderly populations. ${ }^{2)}$ The mean age of NTM patients is between $50-70$ years and advanced age is a poor prognostic factor. ${ }^{3)}$

Mycobacterium abscessus, one of the subspecies of NTM, is an important pathogen due to its increasing prevalence and treatment difficulties due to the potential for multidrug-resistance. ${ }^{1)}$ We report a case of the successful treatment using the combination of clarithromycin and ethambutol of an $M$. abscessus skin infection of a wound caused by shaving in a patient.

\section{CASE REPORT}

A 75-year-old man presented with pruritic, diffuse, variously-sized erythematous papuloplaques and pustules on his neck and chest that had been present for 2 months. The initial lesion was a wound that developed while shaving the hairs on the lateral side of his neck using a wet razor; however, the lesions were spread to his chest in the form of erythematous papuloplaques and pustules (Fig. 1A). He was taking medications for hypertension, renal insufficiency, and stroke. There were nonspecific findings in his family history.

Potassium hydroxide tests of the pustules were negative. Therefore, a biopsy was performed of the chest lesion and Gomori methenamine silver (GMS) staining; periodic acidSchiff (PAS) staining; acid-fast staining; and bacterial, fungal, and mycobacterial cultures were performed using the biopsied specimen. No abnormalities were observed in complete blood cell count and routine chemistry. The histopathologic findings revealed neutrophil and lymphocytic infiltrations, which were consistent with an abscess (Fig. 2A), but the GMS, PAS, acid-fast bacilli (AFB), immunohistochemical staining (Fig. 2B-D), and bacterial and fungal culture findings were negative. Itraconazole 200 $\mathrm{mg} /$ day and isoconazole cream were used for treatment of a suspected deep fungal infection for 1 month, but there was no improvement. On the 32nd day of mycobacterial culture, NTM were observed and the subspecies was confirmed as $M$. abscessus by reverse-transcriptase polymerase chain reaction (RT-PCR) with hybridization. We treated the patient with a combination of clarithromycin $1,000 \mathrm{mg} /$ day and ethambutol $800 \mathrm{mg} /$ day for 5 months, and there has been no evidence of recurrence after 6 months of 

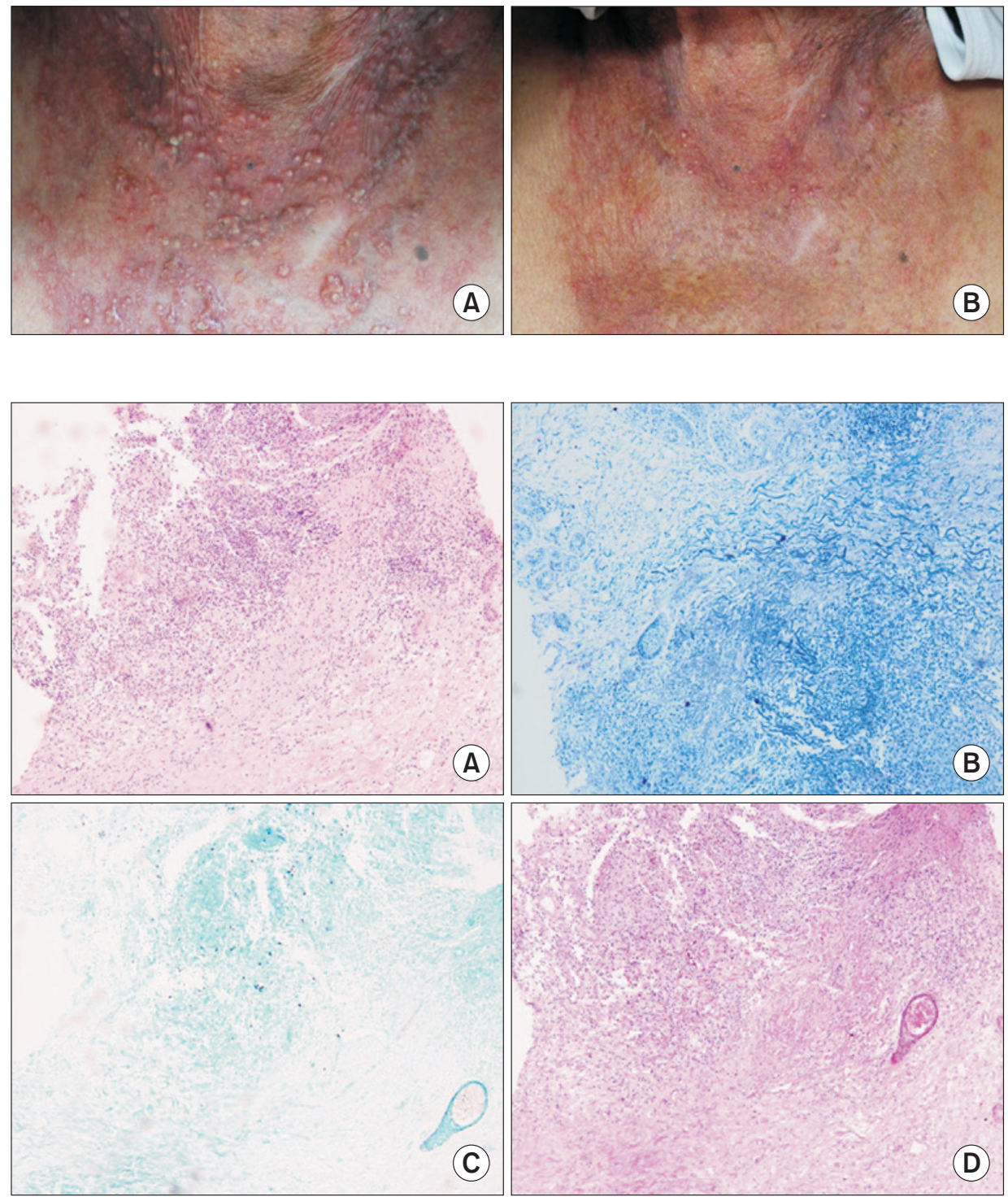

Fig. 1. (A) Diffuse erythematous papuloplaques and pustules on the chest. (B) The lesions were almost cleared after 3 months of treatment with combination of clarithromycin $1,000 \mathrm{mg} /$ day and ethambutol $800 \mathrm{mg} /$ day.

Fig. 2. Histopathologic finding. (A) Numerous neutrophil and lymphocytic infiltrations, which were consistent with abscess $(\mathrm{H} \& \mathrm{E}$, $\times 100$ ), (B-D) Nonspecific findings on immunohistochemical stain (B: acid-fast bacilli, $\times 100$; C: Gomori methenamine silver, $\times 100$; D: periodic acid-Schiff, $\times 100$ ).

Table 1. Cases of Mycobacterium abscessus skin infection in the Korean dermatologic literature

\begin{tabular}{|c|c|c|c|c|c|c|c|c|}
\hline Study & $\begin{array}{l}\text { Sex/age } \\
\text { (yr) }\end{array}$ & Location & $\begin{array}{l}\text { No. of } \\
\text { lesions }\end{array}$ & Skin lesion & $\begin{array}{l}\text { Trauma } \\
\text { history }\end{array}$ & $\begin{array}{l}\text { Underlying } \\
\text { disease }\end{array}$ & Diagnosis & Treatment \\
\hline $\begin{array}{l}\text { Cho et al. }{ }^{11)} \\
(2004)\end{array}$ & $\mathrm{F} / 30$ & Both arms & 2 & $\begin{array}{l}\text { Erythematous } \\
\text { subcutaneous } \\
\text { nodules }\end{array}$ & None & None & $\begin{array}{l}\text { Culture } \\
\text { PCR-RFLP }\end{array}$ & $\begin{array}{l}\text { Roxithromycin, } \\
\text { cefditoren, } \\
\text { amikacin, I\&D }\end{array}$ \\
\hline $\begin{array}{l}\text { Choi et al. }{ }^{12)} \\
(2005)\end{array}$ & $\mathrm{F} / 57$ & Right cheek & 1 & $\begin{array}{l}\text { Erythematous } \\
\text { plaque }\end{array}$ & None & None & $\begin{array}{l}\text { Culture } \\
\text { PCR-RFLP }\end{array}$ & $\begin{array}{l}\text { Clarithromycin, } \\
\text { ciprofloxacin, } \\
\text { I\&D }\end{array}$ \\
\hline $\begin{array}{l}\text { Han et al. }{ }^{13)} \\
\text { (2008) }\end{array}$ & $\mathrm{F} / 32$ & Left shin & 1 & $\begin{array}{l}\text { Red infiltrated } \\
\text { plaque }\end{array}$ & $\begin{array}{l}\text { Habitual } \\
\text { leg shaving }\end{array}$ & None & $\begin{array}{l}\text { Culture } \\
\text { PCR-RFLP }\end{array}$ & $\begin{array}{l}\text { Clarithromycin } \\
\text { cefaclor, I\&D }\end{array}$ \\
\hline $\begin{array}{l}\text { Kwon et al. } .^{14)} \\
\text { (2009) }\end{array}$ & $\mathrm{F} / 71$ & Left forearm & Multiple & $\begin{array}{l}\text { Erythematous } \\
\text { swollen nodules }\end{array}$ & Injection & DM, OA & $\begin{array}{l}\text { Culture } \\
\text { PCR-RFLP }\end{array}$ & $\begin{array}{l}\text { Clarithromycin, } \\
\text { C\&D }\end{array}$ \\
\hline $\begin{array}{l}\text { Chun et al. } \\
\text { (2012) }\end{array}$ & $\mathrm{F} / 48$ & $\begin{array}{l}\text { Back } \\
\text { (injection } \\
\text { site) }\end{array}$ & Multiple & $\begin{array}{l}\text { Erythematous } \\
\text { nodules and } \\
\text { ulcers }\end{array}$ & $\begin{array}{l}\text { Intramuscular } \\
\text { injection }\end{array}$ & None & $\begin{array}{l}\text { Culture } \\
\text { DNA } \\
\text { sequencing }\end{array}$ & $\begin{array}{l}\text { Clarithromycin, } \\
\text { cefoxitin, } \\
\text { amikacin, I\&D }\end{array}$ \\
\hline $\begin{array}{l}\text { Present case } \\
\text { (2018) }\end{array}$ & $75 / \mathrm{M}$ & $\begin{array}{l}\text { Neck, } \\
\text { anterior } \\
\text { chest }\end{array}$ & Multiple & $\begin{array}{l}\text { Erythematous } \\
\text { papuloplaques } \\
\text { and pustules }\end{array}$ & After shaving & $\begin{array}{l}\text { HTN, renal } \\
\text { insufficiency, } \\
\text { stroke }\end{array}$ & $\begin{array}{l}\text { Culture } \\
\text { RT-PCR with } \\
\text { hybridization }\end{array}$ & $\begin{array}{l}\text { Clarithromycin, } \\
\text { ethambutol }\end{array}$ \\
\hline
\end{tabular}

DM, diabetes mellitus; OA, osteoarthritis; PCR-RFLP, polymerase chain reaction-restriction fragment length polymorphism; I\&D, incision and drainage; C\&D, curettage and drainage; RT-PCR, reverse-transcription polymerase chain reaction; HTN, hypertension. 
follow-up (Fig. 1B). The patient gave full permissions for the publication of this paper and use of photographs.

\section{DISCUSSION}

M. abscessus, along with $M$. chelonae and $M$. fortuitum, are rapidly-growing mycobacteria ubiquitous in the soil and water. ${ }^{2)} M$. abscessus can cause infections in all human organs, but most commonly causes skin and soft tissue infections. ${ }^{4)}$ Although the incidence of NTM infection has increased in recent decades, it is unclear whether this increase is due to actual infections or due to technological advances identifying the exact pathogens. ${ }^{5)}$ Nevertheless, the elderly are more susceptible to NTM infection and have an increased morbidity. ${ }^{3)}$

The cutaneous infection routes include direct contact with contaminated materials through trauma or secondary infection in patients with disseminated disease. ${ }^{6}$ The appearance of skin lesions varies among papules, nodules, ulcers, scarring, and mixed forms, and the infection may appear as papules and pustules in some serious cases. The primary cutaneous infections are present on exposed areas that are vulnerable to injury and lesions usually occur locally; however, multiple lesions may occur when the pathogens are spread through the lymphatic system. ${ }^{7)}$ The histologic findings may show lymphocytic infiltration around the blood vessels of the dermis and granuloma caused by eosinophils, plasma cells, and giant cells with no neutrophil component in the deep dermis. Additionally, neutrophilic abscess with mild granulomatous reaction may also be observed. In severe cases of inflammation, neutrophil deposition and edema may be seen throughout the dermis. Generally, systemic symptoms, such as fever and myalgia, are rare. ${ }^{1)}$

M. abscessus can be diagnosed by Ziehl-Neelsen staining, culture in Lowenstein-Jensen or Ogawa medium, and PCR. Ziehl-Neelsen staining and culture may show falsepositive results. PCR is a method used to precisely identify strains by analyzing the results obtained by amplifying the $16 \mathrm{~S}$ rRNA, hsp65, and rpoB genes, which differ in each NTM species. Recently, the sensitivity has been increased by methods such as polymerase chain reaction-rectification fragment length polymorphism. ${ }^{1,7)}$ Identification of the exact strain in the infection is important because they may have different antibiotic sensitivities. ${ }^{7)}$

$M$. abscessus tends to be resistant to many antibiotics, making its treatment difficult. Therefore, if $M$. abscessus is identified, antibiotic susceptibility testing should be performed. A study of antibiotic susceptibility of $M$. abscessus in Korea revealed it to be most sensitive to amikacin (99\%) and cefoxitin (99\%), followed by imipenem (55\%) and tobramycin (36\%) among the parenteral antibiotics. Among oral antibiotics, $M$. abscessus was most susceptible to clarithromycin (91\%), moxifloxacin (73\%), ciprofloxacin (57\%), and doxycycline (7\%). ${ }^{8}$

There is no exact guideline for the treatment of $M$. $a b$ - scessus infection. Clarithromycin monotherapy can generally be used for local infection but should be used with caution because of the potential for antibiotic resistance. Combination therapy with clarithromycin and parenteral antibiotics such as amikacin or cefoxitin is recommended for severe cases. ${ }^{5)}$ In addition, antibiotics should be used for 4 months for mild infections and for 6 months for severe infections. ${ }^{9)}$ Patients with disseminated infections often have poor immunity, so surgical debridement of necrotizing tissue or drainage may be better than antibiotic combination therapy alone. ${ }^{9)}$

We experienced a case of primary cutaneous infection caused by $M$. abscessus in an elderly patient with comorbidities and a history of minor trauma from a razor blade. The lesion might be similar to other diseases such as deep fungal infection and lupus vulgaris. We confirmed the NTM infection and NTM strain using skin biopsy, mycobacterial culture, and RT-PCR with hybridization. Although we could not perform drug sensitivity testing, he was well treated with the combination of clarithromycin and ethambutol.

The incidence of NTM skin infections in older adults has been increasing recently. This increase may be due to decreased T cell and cytokine activities with aging, which are important for the pathogenesis of NTM infection. ${ }^{10)}$ Some cases of $M$. abscessus skin infection have been reported in Korea (Table 1), however, to our knowledge, there have been no other reported cases of $M$. abscessus infection presenting with multiple and diffuse lesions after shaving in the elderly. Decreased immunity in the elderly could be related to the appearance of multiple and widespread lesions. Papules or pustules at the shaving site among those who shave daily may be easily mistaken for folliculitis. When the lesions do not respond to treatment for folliculitis, it is important to perform the necessary tests to identify pathogens such as NTM.

\section{CONFLICTS OF INTEREST DISCLOSURES}

The researchers claim no conflicts of interest.

\section{REFERENCES}

1. Ryu HJ, Kim WJ, Oh CH, Song HJ. Iatrogenic Mycobacterium abscessus infection associated with acupuncture: clinical manifestations and its treatment. Int J Dermatol 2005;44:846-50.

2. Cassidy PM, Hedberg K, Saulson A, McNelly E, Winthrop KL. Nontuberculous mycobacterial disease prevalence and risk factors: a changing epidemiology. Clin Infect Dis 2009;49:e124-9.

3. Andréjak C, Thomsen VØ, Johansen IS, Riis A, Benfield TL, Duhaut $\mathrm{P}$, et al. Nontuberculous pulmonary mycobacteriosis in Denmark: incidence and prognostic factors. Am J Respir Crit Care Med 2010;181:514-21.

4. Nessar R, Cambau E, Reyrat JM, Murray A, Gicquel B. Mycobacterium abscessus: a new antibiotic nightmare. J Antimicrob Chemother 2012;67:810-8. 
5. Uslan DZ, Kowalski TJ, Wengenack NL, Virk A, Wilson JW. Skin and soft tissue infections due to rapidly growing mycobacteria: comparison of clinical features, treatment, and susceptibility. Arch Dermatol 2006;142:1287-92.

6. Kothavade RJ, Dhurat RS, Mishra SN, Kothavade UR. Clinical and laboratory aspects of the diagnosis and management of cutaneous and subcutaneous infections caused by rapidly growing mycobacteria. Eur J Clin Microbiol Infect Dis 2013;32:161-88.

7. Nakanaga K, Hoshino Y, Yotsu RR, Makino M, Ishii N. Laboratory procedures for the detection and identification of cutaneous nontuberculous mycobacterial infections. J Dermatol 2013;40:151-9.

8. Park S, Kim S, Park EM, Kim H, Kwon OJ, Chang CL, et al. In vitro antimicrobial susceptibility of Mycobacterium abscessus in Korea. J Korean Med Sci 2008;23:49-52.

9. Brown-Elliott BA, Wallace RJ Jr. Clinical and taxonomic status of pathogenic nonpigmented or late-pigmenting rapidly growing mycobacteria. Clin Microbiol Rev 2002;15:716-46.
10. Ponnappan S, Ponnappan U. Aging and immune function: molecular mechanisms to interventions. Antioxid Redox Signal 2011;14:1551-85.

11. Cho JH, Kim MY, Park YM, Kim HO. A case of cutaneous infection due to Mycobacterium abscessus. Korean J Dermatol 2004;42:5125 .

12. Choi YL, Lee KJ, Lee DY, Lee ES. A case of skin infection caused by Mycobacterium abscessus. Korean J Dermatol 2005;43:852-5.

13. Han YJ, Choi HY, Myung KB, Choi YW. A case of cutaneous Mycobacterium abscessus Infection. Korean J Dermatol 2008;46:1657-60.

14. Kwon YH, Lee GY, Kim WS, Kim KJ. A case of skin and soft tissue infection caused by Mycobacterium abscessus. Ann Dermatol 2009;21:84-7.

15. Chun SM, Yun SJ, Kim SJ, Lee SC, Won YH, Lee JB. Disseminated Mycobacterium abscessus infection in healthy adult. Korean J Dermatol 2012;50:269-72. 